\title{
Variants of the Transformation Process in Central Europe. A Comparative Assessment ${ }^{1}$
}

\section{Ilja Srubar}

University of Erlangen-Nürnberg, Institute for Sociology, Kochstr. 4, D-81054 Erlangen, Germany

\begin{abstract}
The article examines how far the transformation process in the post-socialist countries can be considered an "ongoing" modernization in Parsons' sense. The starting point of the investigation is a comparison of current developments in Poland, Hungary and the Czech and Slovak Republics focusing on the effects of market and political pluralization on the level of social structure, everyday patterns of action and the changes undergone by elites. Finally, the special case of the former GDR is discussed. Because of anomic effects occurring in the transition process and causing social and ethnic exclusion, disintegration and particularization, the article questions a precipitate evaluation of the transformation process as a positive institutional modernization.
\end{abstract}

\section{The Problem}

When it comes to assessing the transformation process in post-socialist countries, a perspective which has been gaining prominence within German sociology is known as the theory of institutional or "ongoing" modernization (Zapf 1991: 46). This approach supposes that the social structure in postsocialist countries (particularly the former GDR) has collapsed, but sees that as a potential opportunity for successful modernization in the countries concerned (Zapf: 1991a, 1993). According to the theory, it is the advent of modernizing institutions in the decomposed societies of real socialism - as manifested in the implementation of political pluralism, i.e. competitive democracy, the rule of law, a market economy and the welfare state accompanied by mass consumption - which sets in motion the structural mechanisms of modern social integration. Following on from Parsons (1972: 20), the mechanisms identified in this respect, which entail inherent social conflict alongside their integrative effect, consist of social inclusion, value generalization, differentiation and adaptive (status) upgrading. These mechanisms are supposedly the driving forces of "'ongoing modernization' in the dual sense of directional constancy and structural im-

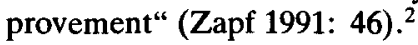

1 This paper is based on a study of the "Collapse of Real Socialism" which has been published as a course text for the Open University of Hagen. Cf. Bertels 1993. The present version has been translated by Neil Johnston.

2 The key passage here (in unofficial translation) reads: "In my view, a modernization theory 'hardened' by conflict theory and innovation theory is the most suitable approach for gaining an understanding of
I would like to subject this concept to some scrutiny in this paper. My purpose here is not to criticize

the upheavals in the east as well as the current problems and future opportunities in the west. Competitive democracy, the market economy and an affluent society with a welfare state and mass consumption are the basic institutions within which the struggle to innovate takes place. The degree of political centralism and the extent of regional disparities, of ethnic/ religious conflicts, of elements of concordance democracy, of class polarization, of the welfare state and of social attachment in the market economy all - in addition to the international position of the society concerned - make up the dimensions of variation in modern societies. Inclusion, value generalization, differentiation and adaptive upgrading are the mechanisms of social change. I call this process "ongoing modernization", in the dual sense of directional constancy and structural improvement." (Zapf 1991: 46).

Zapf certainly recognizes a number of "significant arguments" against the model as presented, and also the existence of "countless phenomena of exclusion, fault-lines, erosion and large-scale risks". Nevertheless, he sees "... no sufficient empirical or theoretical reasons to doubt the innovative capacity of the basic institutions of modern societies" (Zapf 1991: 48). Even though he explicitly points out "... [the] examination of successful innovations, failed innovation attempts and the transferability of modern institutions" (Zapf 1991: 49), his line of argument (aimed mainly against the criticism of the transition in the east voiced by "western Marxists" and taking up an incisive counter-position) nonetheless leaves no room for doubt that, in his opinion, there are "... at present no more effective alternatives [in sight to] competitive democracy, the market economy and an affluent society with a welfare state and mass consumption ... now that socialism is out of the running for the foreseeable future." (Zapf 1991: 47). 
the above modernization theory in and of itself, as it undoubtedly has a good deal of plausibility within the particular sphere of social reality from which it is derived, i.e. the social reality of western industrial nations and of their historical development. Nor do I seek to deny that the institutional structure of western industrial societies provides a benchmark for the transformation processes in post-socialist countries, even if it does tend to vary in its concrete form. Rather, the question I would like to pursue is whether the modernization mechanisms postulated by the theory really do operate in post-socialist reality with the "directional constancy" and "structural improvements" they are evidently assumed to entail.

The immediate theoretical doubt I wish to raise is that a theory of "ongoing modernization" which is ultimately a theory of change, or in other words one which deals with dynamic processes, is being applied here in a manner which does not pay sufficiently close attention to the time factor in the very developments it is attempting to explain. It is not enough for consideration of the temporal dimension of transformation to be confined to naming the period of time within which successful adjustment is likely to be achieved. If one considers the prospect of a collapsed social structure into which institutions are to be implanted in order to provide new structures, it is virtually self-evident that a certain period of time will need to elapse before the new institutions can begin to take hold. And when they do "take hold" the idea that this will give rise to changes in action in the manner intended by the newly implemented institutions is only one, i.e. the most optimistic, of the conceivable scenarios. As Robert Merton ([1949] 1968: $230 \mathrm{ff}$.) has already shown, there are a number of other possible courses developments might take when people adjust to a situation they perceive as anomic. These are the familiar alternatives of withdrawal, ritualism, rebellion and innovation; the latter of these, if it involves the pursuit of systemimmanent objectives using means which do not conform to the system, may well include crime (also including criminal behaviour in government and business), corruption, etc.

In theoretical terms, then, we should not necessarily assume a linear time chart depicting a steady increase in the intended effect of the modernization institutions once implemented; rather, one should assume that the collapse of the social structure in which the institutions are expected to operate will first cause an anomic rift in the linear development imagined in the ideal-typical conception, ${ }^{3}$ or in other words that the imaginary line on the graph will begin by falling away and will not rise again, if at all, for some time. Hence even in the best conceivable adjustment scenario we ought to be dealing with a U-curve effect. However, because we need to regard the course of development as an open-ended process, the inevitable conclusion is that whatever happens in the post-socialist countries during this $U$-curve period can be expected to have a substantial influence on the trend followed by the transformation process.

In order to make better assessment of such processes, we need to be aware of what the successful operation of institutions - i.e. operation which generates their intended effects - depends upon. Institutions operate within a social environment; they not only exert influences upon that environment but are in turn influenced by it. Thus the effectiveness of institutions also depends upon the everyday action orientations and expectation structures of the actors which constitute that environment or, to use Parsons' terms, upon the acceptance of their goals within the system of values and upon the reproduction or modification of those goals within the system of interaction of a particular society.

If we wish to clarify what happens during the Ucurve of the transformation process and to assess the shape of that curve for the transformation process itself, we have to view the effect of the implemented institutions in the context of the social structure of the post-socialist countries, and have to examine the "interaction" of this effect with the semantic inventory of the societies concerned. ${ }^{4}$ The implication of this is that we must turn our attention to the meaning level of the transformation process, i.e. to the expectation structures in everyday action referred to above, which determine both the attitude taken to the process and the orientation of action within it.

3 There would appear to be a considerable amount of scepticism in the central and eastern European perspective with regard to such ideas of linear development and the associated optimistic view of modernization (Stojanov 1992). Others to have voiced their doubts on this include Kabele 1992 and Musil 1992.

4 That the course taken by the transformation process is determined by this "interaction" is especially and repeatedly emphasized by analyses made from the perspective of the affected countries themselves (Sztompka 1993, Musil 1992, Kabele 1992, Brokl 1992). 
There are two fundamental paradoxes ${ }^{5}$ underlying and characterizing the transformation process which this assessment will focus upon:

a) The political and economic institutions of bourgeois, civil society (bürgerliche Gesellschaft) need in this case to be introduced by a plan imposed from above. In other words, they cannot rely on support from any social structure which has grown organically and is complementary to them - quite the opposite:

b) Not only the mechanisms of social organization and the habitualized and institutionalized action orientations available for a process intended to establish true citizenship in post-socialist societies, but also the vast bulk of economic and administrative potential are in fact products of the real socialism which is supposedly being superseded. To sum up, whatever ingredients may be used by particular restructuring recipes, they will still ultimately have to be cooked in the oil or water laid on by real socialism.

The above material paradoxes leave no other choice but to accept a similarly paradoxical scheme of assessment. The upheavals in the social structure in real socialism and the implementation of new institutions have to be viewed against a background in which elements of the real socialist stock of knowledge continue to exert a certain validity and continue to be applied (Srubar 1991). On the one hand, the implementation of a market economy and political pluralism results in the structure of society being turned in on itself; this process, moreover, occurs simultaneously on all fundamental levels, for political and economic restructuring goes hand-in-hand with a deep-seated insecurity in the action orientations of those involved in it. When regarded in structural terms, the effects of these changes create a burst of anomie manifesting itself in the collapse of the economy, of political power and of social integration. ${ }^{6}$ Yet on the other hand, the means of coping with this anomic situation continue to be shaped by actors resorting to the orientations of real socialism, which thus continue to operate on the meaning level during the transformation process. It is this level of everyday action in particular which lends social action at least the appearance of normality, thus partly con-

5 For a thorough treatment of the countless paradoxical implications of post-socialist transformation, see Offe 1991.

6 Enquiries conducted by Czech and Hungarian authors speak of "transformation anomie" (Kabele 1992, Andorka 1992). cealing the structural ruins, but partly building new bridges (Kabele 1992).

Taking this state of affairs as the point of departure, I should like to proceed in two stages. Firstly, I shall examine the effect on social structure in the post-socialist countries of privatization in the economic sphere and pluralization in the political one. I have chosen these two "institutions" because the extent to which they can be successfully implemented will be a crucial factor in determining how far the other mechanisms of modernization theory described above - i.e. competitive democracy, the welfare state, consumption, adaptive upgrading, inclusion, differentiation, etc. will themselves be able to develop. In the second stage, I shall endeavour to portray the most important currently visible elements on the meaning level in which the overall process is embedded. The basis for these considerations will be provided by a comparative assessment of the transformation process in Poland, Hungary, the Czech and Slovakian Republics, and the GDR/new federal states.

The starting point for the first stage of the enquiry is provided below by short sketches of developments in the first four of these countries. A number of the points emerging are then developed in the second stage. The insights they provide into the special characteristics of transformation in the (former) GDR are discussed in more detail thereafter.

\section{Comparative Assessment of the Four Countries}

\section{Poland}

Poland had undoubtedly made the most progress in developing a "civil society" beneath the surface of the ossified society of real socialism. The coalition dating back to the 1970s between intellectual or church opposition groups and the labour movement which prepared the ground for the later formation of Solidarnosc also gave rise to a wideranging social network which, even under martial law, provided the opposition movement with a broad, well-anchored basis in all strata of society (Brus et al. 1981, Ziemer 1989). Although the main reason why an oppositional attitude was so widespread in the working classes was Poland's catastrophic economic situation, the prime source of the opposition movement's cohesion nevertheless lay in its political objectives and anti- 
totalitarian values, ${ }^{7}$ (Frentzel-Zagorska 1990, Michnik 1981, Tatur 1991). The chief concern was not economic reform but the desire to participate in the exercise of power or at least to have an effective means of monitoring that power (Michnik 1981, Marody 1990). The public's economic interests were articulated in the political expectation of greater "social justice" to be achieved by improvements in political transparency and codetermination. Hence they maintained their belief in an idea which is socialist in principle, namely that governmental power rationalized from below via political participation ought to be in a position to serve the economic interests of the general public (Marody 1990: 270). Although there was a marked interest during the $1980 \mathrm{~s}$ in the willingness to accept pay differentials in accordance with levels of qualification, that willingness arose out of a desire to see a socially just distribution of income according to responsibility, performance and education, which by no means automatically implied any acceptance of a distribution of social opportunities determined by the performance principles of the market economy (Buchner-Jeciorska 1992: 237, KolarskaBobinska 1988: $129 \mathrm{ff}$.). Nor indeed did it imply any consent to the fulfilment of a major precondition for establishing a market economy, i.e. the reprivatization of state enterprises. Conflicting views on this problem did not begin to emerge in Polish society until the end of the 1980 s. Opinion research has shown a positive correlation between acceptance of privatization and higher levels of education and social status (Kolarska-Bobinska 1988, Kolarska-Bobinska/Rychard 1990). The practical consequences of this are shown in three tendencies, the first two of which also apply to the other countries considered here:

a) Privatization provides the opportunity to carry out the redistribution of goods and services which previously occurred on the black market on a new, legal basis. The groups within society which in the past had the property, qualifications, mobility, and the right positions in social networks needed to carry out their black-market activities are now in a position to use the same factors to help them set up new businesses under the new circumstances prevailing, possibly also using this as a means of compensating for the loss of their jobs. From the workers' point of view, however, their ability to participate in the black market normally entailed depriv-

On the more concrete form of the "anti-totalitarian values", cf. the section on "Civil Society" in this paper. ing their employers either of their labour input or of materials. For them, privatization not only threatens their existing jobs, but it also blocks off their access to other resources which might serve as some compensation.

b) Those who belonged to the "old structures" and the black-market profiteers of old accept privatization as an opportunity to maintain their social positions by using both their inside information and their illegally accumulated capital to now set themselves up legally as free entrepreneurs. ${ }^{8}$

c) A schism has now opened up between the new élite of the former opposition and the grass roots of Solidarnosc in the state-owned enterprises yet to be privatized, whose workforces are resisting any such change (Kuron 1993). While the élite wants to push ahead with privatization so that it can fulfil the International Monetary Fund's conditions and enhance the country's attractiveness to foreign capital, people at the grass roots are rising up against the threat of losing their jobs by appealing to the original aims of the Solidarnosc movement, turning now against the new government of the day. ${ }^{9}$ So here we see the two faces of "civil society" - one of which is rooted in the conditions of real socialism and the other of which is the liberal face made possible by transformation - are confronting one another as conflicting parties. Each of the two sides still claims its own legitimacy in terms of anti-totalitarian values, but there are substantial differences between them on interpreting those values. The electoral victory of the Left shows how great the pulling power is of expectations which grew up under real socialism that a "civil society" will take care of its citizens too. That, of course, does not mean to say that the conflict giving rise to that victory has been resolved. As the government has been relatively hesitant to interfere in the process of privatization (Heidenreich 1994), the final result will still be just a core group of nonprivatized state enterprises. As those affected increasingly tend to equate "privatization" with "selling out the economy to foreign capital" (Ludwig 1992, Kuron 1993), the conflict has also now

8 Cf. Beckherrn 1991: $33 \mathrm{ff}$. on the situation in Poland, Mateju 1992 on the Czech and Slovakian Republics, and Koch/Thomas/Woderich 1993 on Hungary and the GDR.

9 Apart from sit-ins, strikes and mass demonstrations against "the robbery of privatization", this conflict is also now already showing additional signs of nationalist and anti-Semitic tendencies (Ludwig 1992). A continuation of the conflict is also apparent in the newly-elected, left-wing Pawlak government. 
taken on a "nationalist" component. The high value placed upon matters national in the semantic inventory of Polish society (Staniszkis 1991, Offe 1993a) lends an excursive power to this kind of definition of the conflict which, in view of the disappointment now rife among the majority of the general public following privatization (Kuron 1993), ought not to be underestimated. Under these circumstances, there is some plausibility to Polish analyses which neither exclude the possibility of privatization being forced through in an authoritarian manner against the wishes of parliament, nor that of populist reactions occurring against the process (Bobinska/Rychard 1990: $317 \mathrm{ff}$.).

\section{Hungary}

Events in Hungary allow an ideal-typical picture to be built up of how an "alternative" society can be constituted within the framework of real socialism, or in other words of a case almost diametrically opposed to that of Poland. The unerring efforts of Hungary's party leadership to use whatever practical political scope was available to institute economic reforms opened up the opportunity during the 1980 s for a "second society" to develop by legalizing the shadow economy, i.e. by instituting a second wave of private-sector economic reform to add to the reforms already carried out in the state sector (Hankis 1988, Manchin 1988, FrentzelZagorska 1990). The new secondary economy allowed Hungarians not only to set up their own businesses, but also to take up activities in the private sector as a supplement to their continuing employment in the state sector. This meant that between $50 \%$ and $60 \%$ of the population were able to participate in the two economic forms (Manchin 1988: $88 \mathrm{ff}$.). Thus even while real socialism persisted, inequality in the distribution of income began to grow and the relative positions of the rich and the poor which had previously been characterized by real socialism began a process of marked change. The move to "economic citizenship" in Hungarian society, which at the same time incorporated the latently ubiquitous desire for a normalization of society in line with the antiauthoritarian values propagated by the élite of Hungary's opposition - once again put the country's communist leadership under pressure to make yet more reforms. For one thing, the need arose to channel the money earned in the secondary economy back into the primary sector of the economy, and this was the origin of the idea of setting up a stock exchange on which shares in state-owned enterprises could be traded. For another, the social differentiation process resulting from the secondary economy brought shifts in the distribution of income which were detrimental to the communist functional élites of bureaucrats and technocrats (Galasi 1985), spurring the latter to look for ways of capitalizing on the power they had in their hands to transform it into legitimate economic positions in the context of a reform movement. ${ }^{10}$ The predominance of reform tendencies within the communist leadership then made it possible to maintain relations with the opposition élite, which was thus able to bring its influence to bear upon the Party to persuade it to accept political pluralization (Bruszt 1990, Mänicke-Gyöngyösi 1991). Although public approval of the political pluralization introduced by this negotiated "revolution from above" (Bruszt 1990: $367 \mathrm{ff}$.) was high, opinion remained divided as far as the privatization of industry and agricultural enterprises was concerned. Approximately $60 \%$ of opinion poll respondents said they favoured keeping land under cooperative ownership, while they felt industrial enterprises should be either state-owned or administered directly by their workforces. Meanwhile, $38 \%$ were in favour of privatizing enterprises by returning them to their former owners or putting them up for sale. The number of Hungarians in favour of privatizing agricultural land is lower still (Hankis 1990: 182-3).

There are two factors which may serve to explain why, when the secondary economy was legally put into practice with an associated real acceptance of economic inequality, this did not have a more positive influence on the attitude towards privatization. The first is the prevailing attitude towards the state-owned sector based on a dual morality which, on the one hand, sees a source of security in retaining employment in state-owned enterprises, and on the other sees the opportunity to use the resources of these enterprises for private purposes. Here too, fear of eventual unemployment has its part to play. The second factor may lie in the functional élite's knowledge of the structure of Hungarian industry, built up as it was under socialist conditions and being organized into just a small number of very large combines: deglomeration and privatization of the combines would cause serious

10 This is the explanation provided by Mozny (1991) for the willingness of communist leaderships to negotiate rather than to use force against their opposition. 
problems and the loss of many jobs. This hesitancy to engage in the radical shock therapy of privatization both among the general public and among the functional élites evidently increased the appeal to the new leadership of a third way with a mixed economic system (Horn 1992, Andorka 1992a: 216f., Lukács 1992). This caution is also natural in the face of the pronounced polarization which has occurred in people's economic situations. In 1992, only $13 \%$ of the population felt that their position had remained unchanged, while $50 \%$ believed it had worsened and $37 \%$ believed it had improved (Andorka 1992). In Hungary too, the polarizing effects of transformation on the social structure are developing the potential to generate delegitimating effects. Once again, an extremely nationalistic populism is already developing to question the integrity of the current leadership from the right by accusing it of acting as a "demokratura".11 The same tendency has also allowed the socialist opposition to regain a certain amount of political weight.

\section{Former Czechoslovakia}

Although the Czechoslovakian opposition movement Charta 77 was well known in the world's media, it was not actually very large in size and was socially relatively isolated. Thus the model of civil society oriented to community networks of dissidence gained relatively little recognition as a "concrete utopia“. Charta 77 did provide a means of articulating the general consensus of dissatisfaction with the regime, yet it did not have any mass, grass-roots basis. Rather, its main sounding board was among the "grey stratum" of the educated middle classes and intelligencia (Siklová 1990) who, though they maintained a truce with the regime as fellow travellers, nevertheless experienced the abnormality of it in their everyday lives. Not only for these strata but also for the majority of the general public, the most likely conceivable alternative to the existing regime was a democratic, parliamentary state guaranteeing the rule of law, something along the lines of the pre-war Czechoslovakian republic. After the peaceful revolution, this did indeed become the substance of the new concept of civil society and was disseminated as such by the media (Havel 1991: $44 \mathrm{ff}$., $106 \mathrm{ff}$.). The radical privatization concept also appeared compatible with this understanding of civil society, and

11 On emerging right-wing populism, cf. Hefty 1992 and Konrád 1992. it did indeed assert itself as the new economic policy. As surveys have shown - and as was equally clear by observing social reality - both the pronounced identifications of political pluralism with the first Czechoslovakian republic and the radical push towards privatization combined to drive Czechoslovakian society down a road which would ultimately tear apart the unity of the nation. As shown above for Poland and Hungary, the effects of privatization and attitudes to it divide society in former Czechoslovakia into two separate groups: whereas the less well-qualified and relatively uneducated strata see the security of their social positions being eroded by privatization and fear cuts in their income or unemployment, the middle classes sense that they have an opportunity to better their position (Mateju 1992, Vecernik 1991).

What would appear at first sight to be the normal expected adjustment to the stratification patterns of capitalist society takes on a completely different hue if the trends in what are now two different republics are viewed separately. Even in 1992, that is to say before partition, acceptance of the political and economic transformation in the Czech Republic was over $60 \%$, whereas only $30 \%$ of respondents showed a positive attitude to the changes in the Slovakian Republic. In Slovakia, the pre-war republic of the combined nations was not regarded at all as a model for the new democratic state. Around $40 \%$ of people polled in Slovakia said they were prepared to disregard a democratically elected parliament and a constitution established on that basis (against $27 \%$ in what is now the Czech Republic). Likewise, the threat to social security posed by privatization is perceived much more keenly in Slovakia. There, the majority blame the economic ills of the present day not on the mismanagement which occurred under socialism, but on the post-socialist reforms (Butorova 1992).

Quite evidently, two different patterns of interpretation had begun to crystallize, and these differences cannot be explained solely in terms of the nationalist tensions which previously were latent and now had the opportunity to burst to the surface once again. Although that is indeed indicated by the low proportion of Slovakians equating democracy with the pre-war Czechoslovakian republic, there is also another phenomenon at play here: a pattern emerges of different levels of identification with the real socialist past, and a substantial gap in the willingness to deal with that past by engaging in radical privatization of state-owned enterprises. This is a late consequence of the differing levels of development of the two parts of the 
country at the time they began their forty-year period of real socialism. Whereas the Czech Republic, which was already highly-industrialized and quite socially differentiated, experienced the socialist era as a period of demodernization in its societal structure, Slovakia actually went through its strongest period of industrialization during these forty years, bringing a pronounced improvement in the standard of living and also an increase in its own political influence within the nation as a whole. Quite evidently, the egalitarianism which developed under real socialism, accompanied by the expectation that the state would cater for personal needs and thus bring about social justice, became much more deeply associated on a longerterm basis with the notion of economic and social security in Slovakia than in the Czech Republic. The feeling that the reforms originating in Prague were threatening this past security was further reinforced by the awareness of economic and political dependence on the Czech portion of the nation. That opened up a window of opportunity for a left-wing, populist movement which wanted, by partitioning the state, to slow down the reforms or at least bring them under its own control; on that basis, this movement was also able to assert itself against the conservative nationalist tendency also existing in Slovakia. In view of these evident leftwing tendencies, the Czech leadership was at pains to keep its own reform course intact and hence accepted, or indeed itself encouraged the partition of the state.

Of course, partition did not eliminate the sources of social conflict arising as life chances and standards of living continued to drift apart. Although expectations of an improvement in the economy are much greater in the Czech Republic than in Slovakia, $50 \%$ of Czechs and approximately $60 \%$ of Slovakians believe their personal economic situations have worsened, while $20 \%$ in the Czech Republic and $11 \%$ in the Slovakian count themselves as gainers (Slejska 1993). In spite of its radical neoliberal rhetoric, the Czech government is still compelled to keep a protective arm around the majority of large enterprises for the sake of avoiding mass unemployment. ${ }^{12}$ Even though the current economic position of the Czech Republic would appear to be considerably more stable than that of

12 Over $50 \%$ of the Czech Republic's gross domestic product is attributable to government institutions; the share of the private sector is currently estimated at $45 \%$ (against $60 \%$ in Poland and $50 \%$ in Hungary) - source: Lidove Noviny 13.1.94. the other countries under review, if its large industries were to be radically privatized or compelled by any other means to function strictly according to the laws of the marketplace, this would bring a considerable loss of jobs. ${ }^{13}$ The converse situation can be found in Slovakia. Because of the desire to attract investment capital from the west, it is recognized - whatever the rhetorical objections made to shock therapy - that privatization offers the only way of achieving this. One can expect the ultimate consequences to be the same in both of the new republics.

Partition has also failed to put an end to ethnic tensions, and all that has happened is that they have been channelled in new directions. In Slovakia, elements with a pronounced nationalist colour can be detected in the attitudes taken to political and economic developments. These are manifested in a relatively-high incidence of anti-Semitism, in misgivings applying to the Hungarian minority and finally in the negative attitude towards foreign capital $(65 \%)$ (Butorova 1992, Slejska 1993). In the Czech Republic, too, there are tendencies in the political arena which could charge the social conflicts now breaking to the surface with additional nationalist or ethnicist potential. A populist, rightwing "Republican Party" has been making use of the tension between Czechs and Sudeten Germans to stoke up nationalist sentiment, and has been supported in this by the post-communist left. In the heart of the country, the gypsy minority is particularly liable to encounter hostile attitudes. Meanwhile, at the regional level tension is also apparent between Bohemians and Moravians when it comes to rearranging the federal structure.

\section{Consequences of Privatization}

The upheavals in social structure and associated lifestyles in what used to be real socialism are at their most evident in as far as they result from the restructuring of the economy. ${ }^{14}$ The main implica-

13 A characteristic example of this hesitancy was the repeated postponement of the date when a set of laws would take effect which would have allowed stateowned enterprises in the Czech republic to declare

bankruptcy. Even now that they have been passed, the laws are not applied despite the huge mutual indebtedness of the large enterprises which are strictly insolvent. (Heidenreich 1994).

14 The basic economic parameters for the countries under review are as follows: Poland - unemployment rate $15.2 \%$, inflation $1989 / 90: 700 \%, 1991 / 92: 60 \%$, 
tions of the privatization of the economy instituted after the collapse of communism include, on the one hand, the elimination of government subsidies, the break-up of central control institutions and a reduction in over-employment by way of rationalization and closing down certain enterprises. The consequences are unemployment (hitherto unknown in these countries), high inflation and a drop in gross national product. On the other, privatization has released new economic impetus, which in turn has set in motion the development of social inequality and social mobility. The distribution of income and wealth have now begun to take on the broad ranges familiar to us from statistics in western European countries, with the whole spectrum from unemployed single parents through to multimillionaires (Andorka 1992, Beckherrn 1992: $42 \mathrm{ff}$., Stieler 1992). In the process of primary capital accumulation now gathering pace, wealth obtained not only from ordinary black marketeering but also from the secret business transactions of the nomenklatura was now able to be legalized. Yet another effect of privatization, though, was that occupational positions, the significance of which for social status and income distribution had become blurred under real socialism, now once again took on the importance of real starting conditions for social and economic advancement or decline. The main determinants of these starting conditions are:

a) the structural context of a particular occupational stratum or position under real socialism,

b) the newly-emerging rules of the real labour market,

c) the specific manner in which privatization has been conducted in particular countries.

1992/93: 44\% ; Hungary: - unemployment rate $12.6 \%$, change in GDP $1989-1992:-12 \%$, inflation 1989/90: 29\%, 1990/91: 35\%, 1991/92: 20\%; Former Czechoslovakia: unemployment rate $3 \%$ in the Czech Republic (CR) and $13.3 \%$ in the Slovakian Republic (SR), change in GDP 1989-1992: -17\% (industrial production -25\%), inflation 1989/90: 45.6\%, 1990/91: $25.8 \%, 1992 / 93$ : (CR) $18.2 \%$ and (SR) $25 \%$; Former GDR: unemployment rate $17.1 \%$ (see also footnote 18), change in GDP 1990-1992: $-43 \%$ (industrial production $-60 \%$ ).

Source for the data on Poland: Hospodárské noviny 10.3.92, p.29, 13.7.92, p.1; for former Czechoslovakia, Hospodárské noviny 20.3 .91 , p.1, 5.2.92, p.1; 19.4.92, p.1, 7.9.92, p.1; for Hungary, quoted from Andorka 1992, p.9; for the former GDR, DIW Wochenberichte 39/1992, p.468 and Frankfurter Allgemeine Zeitung 7.10.92, p.13, 1992-3 data taken from Lidove Noviny 13.1.94.
On a): In this context, those who appear to be most threatened with social decline are blue-collar and middle-grade white-collar employees in productive and administrative roles who have a low level of qualification, and whose jobs are tending to be lost by rationalization measures or the break up of enterprises and organizations which have a poor output or are politically no longer desirable. The people affected also appear to have clearly recognized the consequences of this tendency for themselves..$^{15}$ Conversely, as is hardly surprising, people in occupations involving a higher level of qualification believe they see opportunities for upward mobility. Evidently also in this category are members of the former functional élite, i.e. technocrats, administrative experts and members of party and ministerial bureaucracies, all of whom have been able, during the course of privatization, to gain control over portions of former government property by establishing new firms of their own. ${ }^{16}$

On b) above: The demand for all types of services, the dissemination of new knowledge, the advent of a more open economy and the resulting opportunities for greater mobility now provide a whole variety of opportunities for people to set up new businesses in the service sector or in commerce. Those who have now left their old jobs in administrative and productive spheres are now keen to enter this market, and predatory competition is the result.

15 Andorka (1992) cites statistics showing that $49.2 \%$ of the Hungarian population suffered falls in their real incomes between 1989 and 1991, 14.7\% saw their incomes rise substantially, while $5.3 \%$ saw them rise several times over. Surveys conducted by Mateju 1992 , and Vecernik 1991 show about $45 \%$ of respondents counting themselves in the lesser-qualified category facing economic and/or social decline. Polarizing trends in expectations have also been established for the former GDR (Zapf 1991, Berger 1992), although the overall real standard of living has remained stable or risen on average (Köcher 1992, Ebert 1993). According to Ebert (1993: 329) the economic situation has remained unchanged for $49 \%$ of poll respondents, is improving for $37 \%$ and is worsening for $21 \%$.

16 This observation is made, for example, by the former Czechoslovakian foreign minister, Jiri Dienstbier, in: Lidové noviny, 8.9.92, p. 8. In Poland too, some who belonged to the old technocratic élite continue to manage former state-owned enterprises now that they are under private control (Beckherrn 1991: 40f.); the same trends are also identified by Kolosi/ Rona-Tas 1992 in the case of Hungary, Koch/Thomas/Woderich 1993 in the case of the former GDR, and Mateju/Tucek 1992 for the Czech republic. 
One structural characteristic clearly in evidence as the employment structure changes in accordance with the rules of the late-capitalist labour market is that a large number of female employees have lost their jobs. ${ }^{17}$ Freedom of movement between countries, and exchange-rate and wage differentials are giving rise to a migratory movement of those seeking work, along an east-west axis. While eastern Germans travel to western Germany to find work, Poles, Czechs and Hungarians are seeking employment in eastern and western Germany. Meanwhile, in Poland, Slovakia and Hungary themselves, cheap labour is now available from the Ukraine, Russia and Romania.

On c) above: a substantial influence on the distribution of starting opportunities is exerted by the manner in which the privatization itself is carried out. To begin with, this has a determinative effect on the level of unemployment. For example, enterprises in Germany's new federal states lost their eastern markets overnight as a consequence of monetary union, and the radical privatization policy of the Treuhand organization ("privatization before rehabilitation") brought the loss of more than four million jobs, ${ }^{18}$ whereas the strategy of coupon privatization being applied in former Czechoslovakia, particularly in Bohemia, would appear to be generating less unemployment in its wake. An important factor here is that the Treuhand has maintained a firm policy of selling only to outside investors with adequate capital, while other countries are aiming to practice various types of "people's

17 This appears to be a universal trend in all of the countries under review: see Stieler 1992, Titkow 1992, Cermakova 1991.

18 Of the approx. 9.7 million people previously employed in the GDR, approx. 6.2 million have retained a job. Of the 3.5 million who lost theirs, 1.1 million are officially unemployed, while the rest are working short time, on job creation schemes, retraining or commuting to the west - data from the Federal Labour Agency reported in Frankfurter Allgemeine 7.10 .92 , p.13. However, these figures do not properly record the "hidden reserve" of unemployed people not registered as such, and the figure for people currently in work must therefore be regarded as too high. A suitably adjusted estimate of the number of jobs lost is therefore in the order of 4.5 million (Müller-Hartmann 1993: 304). If one then also considers that particular industries such as textiles or leatherwork have seen the loss of $60 \%-80 \%$ of the jobs they originally provided (Frankfurter Allgemeine $12.10 .92, p .15$ ), it will be readily apparent that regional pockets of unemployment are well above the overall average rate. capitalism", with a view to raising the acceptance of privatization as such. ${ }^{19}$ It seems the governments in Prague, Warsaw and Budapest would prefer to postpone what most agree is the necessary step of exposing large-scale industry to free market forces. Another source of new opportunities for establishing private businesses is the restoration of land and buildings to their original owners. Here too, significant local differences can be found. For example, in the Czech Republic this factor is already beginning to play a significant part in the emergence of a new class of small and mediumscale business proprietors, but in the new federal states of Germany two-thirds of the applications made for restoration of title have come from the western part of Germany, ${ }^{20}$ thus restricting the opportunities for former citizens of the GDR to establish small and medium-sized firms of their own.

The fact that the redistribution of starting opportunities and social positions has occurred so suddenly is generating a substantial amount of status insecurity. ${ }^{21}$ When this effect is combined with the surviving dual morality of real socialism, status insecurity makes the pure biological or social chance of belonging to a particular ethnic group or community take on a new significance as a final haven of safety. In this respect, polarizing interpretational schemes in the shape of nationalism, all manner of forms of aggressive regionalism and rehashed mythologies of the past tend to reemerge to provide legitimation for these last havens of security. ${ }^{22}$

\section{Consequences of Political Pluralization}

Political pluralization in the countries under review, the acceptance of which was the key point of consensus when it came to sweeping aside the oneparty rule of real socialism has, as far as it is possible to observe, already passed through three phas-

19 See footnote 14 for details on unemployment in former Czechoslovakia. For a comparison of the privatization strategies pursued in the various countries under review, see Stark 1992 and Heidenreich 1994.

20 Allensbacher Berichte No. 7/1991, p. 3. On the development of new small enterprises in the new federal states, see Koch/Thomas/Woderich 1993.

21 On status insecurity and the reorientations is triggers, see Koch 1991 \& 1992.

22 For an earlier view of the biological legitimation of identities, cf. Plessner 1982: $166 \mathrm{ff}$; on the postsocialist variant, see Siklova 1991. On nationalism and the formation of nationalist myths as consequences of societal upheaval due to modernization processes, see Gellner 1991 \& 1992. 
es since the transition from communist power. ${ }^{23}$ Following the original undermining of the power of the Party by alternative élites (phase one), political forces then began to crystallize in a new form which increasingly restricted the influence of the dissidents, i.e. of the original transitional élites (phase two). The newly-emerged interest groups crosscut the original movements of collective opposition. Their representatives, now legitimately elected, no longer project their images primarily by resorting to the original "anti-totalitarian" values of dissent, but by putting forward programmes which respond in a challenging or critical way to the problems associated with the new social and economic distinctions in society (phase three). That now takes the process of political differentiation into a fourth phase in which one of the crucial questions will be whether the "anti-totalitarian" values already have a latent effect, meaning that people will want or be able to uphold these values even in the face of the economic and social sacrifices already being made or still to be expected. This factor is of vital significance to what happens during the U-curve. I shall return to the theme later when dealing with élites.

The second crucial factor during this new phase is the attitude to the process of privatization, which will now be seen either as the cause of such sacrifices or rather as the opportunity to overcome them. The link in interests between the various party political opinions now beginning to crystallize on either side of this dividing line and the shake-up in the pattern of living situations and potential client-groups brought about by privatization would appear not to be very highly developed as yet, so it is hardly yet possible to speak of competitive democracy. The new élites did not come to power as upholders of the interests of particular social groups (Meyer 1993). Instead, the parties and clientèles currently on the scene are distinguished for the time being according to their own internal criteria, i.e. the wish to maintain power for the former and the improvement, maintenance or loss of social position for the latter, without the two sides having yet formed any firm "interest communities". The process in which parties seek a

${ }^{23}$ Translator's note: the German term "die Wende" (the turn) clearly expresses a pronounced change of direction and the opening of a new chapter - for the remainder of the paper "transition" and "transitional élites" will be used for want of better alternatives to convey this meaning, and hence to refer to the period of abrupt change (or the peaceful revolution) as the old real socialist regimes were brought down or fell. suitable electorate, while voters now uncertain of their own status seek suitable bodies to represent their interests, is only just beginning. The volatile switches in the electorate's preferences from right to left currently apparent in Poland, Hungary and the former GDR, may be regarded as a manifestation of this process. As far as the potential political responses to the consequences of privatization are concerned, there are several options for the future development of the system, spanning from the classic combination of a market economy and parliamentary democracy, via a "third way" in a number of different guises, to anti-liberal populism at the other end of the scale.

Events so far in the four countries in question in fact show features of all three of the above variants. In all of them, there is a certain reluctance to really tackle large-scale privatization, and in Hungary this goes hand-in-hand with the rejection of shock therapies and considerations of a possible third way (Stark 1992, Horn 1992, Andorka 1992a). Simultaneously though, a right-wing populist movement has developed which has split away from the governing party. Hungary's socialist opposition, too, is recovering strength. In Poland, the enforcement of privatization in the face of resistance from the workforces concerned has now brought the Left back into government. It now appears to be in the realm of the possible that privatization will be supported by the use of extraparliamentary special powers as a countermove to these changes. ${ }^{24}$ In former Czechoslovakia, acceptance of political and economic liberalism in the Czech part of the country confronted a much greater scepticism towards privatization and leftwing populism in Slovakia. The collision between these contrary options in the context of a newly awakening nationalism sealed the final collapse of the combined nations.

\section{The Meaning Level in the Transformation Process}

As we have seen, even at the structural level of the transformation process, differing configurations can be identified which may produce quite substantial local variations in the path traced by the process as a whole. However, if one wishes to pen-

24 Groups favouring this option were already in evidence in Poland before the change of government. See Kolarska-Bobinska 1988 and KolarskaBobinska/ Rychard 1990. 
etrate through to the manner in which these variants develop their own concrete shape, then identifying common structural prescriptions and constraints arising from privatization in the economy and pluralization of politics in the real socialist environment can only be the first step in that direction, and not a sufficient one. It is equally important to examine the semantic inventory ${ }^{25}$ related to that environment, or in other words the meaning level underlying the prevailing action orientations and expectations in which the social mechanisms of everyday organization and the long-term acceptance of government, political or everyday social action are embedded. To attain a faithful picture of these local variants in the transformation process, then, it is important to find some way of gaining access to and visualizing this meaning level. I would like to draw particular attention to the following elements of the semantic inventory, which are relevant to the question posed in this paper:

1. The first key element is that of collective selfdefinition. The expression applies to a number of aspects indicating how individuals and social groups locate their own positions during the transformation process and/or the attitudes they adopt to it. The first constituent aspect is the "concrete utopia" (Horkheimer 1988: 193ff.) inherent in socially recalled tradition, which fixes certain societal development options and action preferences not yet realized to each actor's horizon of relevance. Also included in this are attitudes to what, having been legitimated by that utopia, eventually becomes social reality and shapes people's conduct of their lives by its structural presence in the real world. Whereas the utopia is normally articulated by the definitional power of élites, ${ }^{26}$ and especially of the intellectuals, the second aspect is manifested in the momentary pictures obtained from opinion polls. The second of the two aspects also throws light upon a horizon of relevance, but in this case it is shaped by everyday action, just as it also provides orientations for it.

2. A second element of importance when considering the meaning dimension of the transformation process is the social acceptance of the definitional power of élites cited above or, turned the other way, the ability of the intellectual élite to exercise its definitional power on a legitimate basis.

25 I choose this term as a development of Luckmann's concept of a communicative budget (Luckmann 1986: 206).

26 The concept of definitional power is used here as by Berger/Luckmann (1970: 116).
Following Eisenstadt, one may formulate this in the terms that élites with a strong cohesion and a high degree of legitimated definitional autonomy can be classed as successful carriers of transformation processes (Eisenstadt 1979: 355).

3 . The means used by élites to exercise their definitional powers have their roots in the existing semantic inventory, and especially in whatever orientation this contains for conducting everyday life. Thus everyday orientations and expectation structures must be taken as a third important element for the meaning level in transformation processes.

4. These orientations and expectation structures are also associated with corresponding typical action strategies and typical structures of social relations, and they give shape to the level of concrete actions and goal attainment as well-proven problem-solving practices. As such, they too constitute a fourth element of significance for the meaning level in the transformation process.

With regard to the substrata of action orientations denoted by the above elements, a number of general aspects can also be pointed out which have brought forth familiar patterns in the transformation process in the countries observed. With the exception of the first of these aspects highlighted. namely dual morality and networks, I shall treat them below by looking first at Poland, former Czechoslovakia and Hungary, going on later to take a separate look at the special case of the new federal states (former GDR).

\section{Dual Morality and Networks}

I proceed first to sketch briefly the everyday action orientations and practices shaped by real socialism and mentioned in points 3 and 4 above, because they serve, as it were, as a life-world foundation for self-definition and legitimation, and make their effects felt upon them.

A characteristic, paradoxical consequence of the planned economy system originally designed to be rational and transparent was the sheer unpredictability caused by its insurmountable problems of coordination, allocation and distribution. This led, both in government and private spheres, to the development of alternative social redistribution networks which were absolutely vital for the system to continue functioning; these constituted the broad area generally known as the shadow economy, though it also at times took on legal forms, as in the case of provision for the top officials of the "nomenklatura". Owing to the principle that party 
decisions were to take priority over any existing statutory regulations, this institutional unpredictability also extended into the all-embracing field of governmental administration. Here too, a system emerged for securing and redistributing output and services - in other words, a system of patronage and corruption - which was closely intermeshed with the redistribution networks in the economic sphere (Srubar 1991). If "civil society" is understood to mean the manner in which citizens organize themselves in order to realize those interests the system cannot cater for, then it was these redistribution networks which made up everyday civil society under real socialism.

The effect of this upon action orientation was to create a "dual morality": ${ }^{27}$ on the one hand, this rejected any restrictive dependence on the state and denied total loyalty to its institutions even though membership of them was retained; on the other hand, making use of precisely those institutions and membership positions within them for the purposes of upholding one's own supply networks was positively sanctioned. This dual morality in which passiveness or reduced effort towards the public sphere contrasted with active private initiative in the context of people's own networks, generated increasing insularity in society along the lines of an exclusive morality which applies differing in-group and out-group criteria, while combining its friend/foe perspective with a preference for resolving all manner of problems by way of private relationships (Srubar 1991: $423 \mathrm{ff}$.). This dual morality of networks and its inbuilt mechanisms of social inclusion and exclusion have continued to function after the revolution as the preferred patterns of action and communication. Their effects which, on the one hand, are exclusive, but on the other engender solidarity, are now being amplified by the redistribution opportunities inherent in the new political and economic orders.

\section{"Civil Society" as a "Concrete Utopia"}

The concrete utopia buoying up opposition thinking in central Europe can undoubtedly be taken to be the concept of "civil society" which developed on a parallel basis in Poland, Czechoslovakia and Hungary ${ }^{28}$ This is naturally considerably different

27 For an early treatment of the phenomenon, see Nowak 1988; for a further systematization see Marody 1988.

28 See Michnik 1985, Havel 1990, Konrád 1984 and, for a comparative view, Ash 1990: 188ff. and Stammer in substance from the real socialist "civil society" of the shadow economy, though it is indeed rooted in it as far as the logic of its actions is concerned. As the concrete utopia of the dissident movement, civil society stands for the idea of societal order flowing from the organization of citizens on their own initiative and underpinned by the ideas of political pluralism, social discourse and tolerance. Associated with this is a bedrock of fundamental values, on which Ralf Dahrendorf cites T.G. Ash as follows: "For the Poles and Czechs, [since 1945, undoubtedly also for the Hungarians - I.S.] Central Europe had always been Western, rational, humanistic, democratic, sceptical and tolerant. The rest was considered to be East European, Russian, or possibly German." (Dahrendorf 1990: 111). Belief in these "anti-totalitarian" values as a concrete utopian project for the future is nurtured, on the one hand, by an idealized past of Europe's civic (bürgerlich), anti-authoritarian traditions, thus apparently supporting Habermas' thesis of the past as the future (Habermas 1990: 74ff.). On the other, albeit through rose-coloured spectacles, it generates the concept of a future in which "normal" conditions will return to society once totalitarian suppression is removed (Havel 1990: 115, Konrád 1984). Against the backdrop of a latent consensus on the abnormality of everyday life under real socialism, the indeterminate expectation already mentioned of normalization, civilization and humanization in society began to crystallize, in conjunction with an equally indeterminate, grouprelated general perspective of social justice. This formed the basis for the latent rejection of the regime on the everyday level (Andorka 1992a, Bauer 1991, Ziolkowski 1988).

However, the integrative effect of such a concrete utopia of civil society is counteracted by a number of other elements derived from the real socialist context in which the construct was developed, as outlined below.

Firstly, the conceptions of how civil society should be socially realized may ultimately prove counter-

1993. Readers will appreciate that this is not the place to delve into the origins of the term or its history since the 17 th Century - on this, see works such as Shils 1991 and Taylor 1991. The fundamental distinction between the traditional bourgeois concept and the idea of civil society as discussed in this context is that the latter was not linked to the factual existence of a market economy or with the idea of institutionalized political authority. Cf., e.g., Tatur 1991, Ash 1990: 203ff. 
productive. ${ }^{29}$ The idea of an "institutionless" society organizing itself against a totalitarian power could be seen being put into practice in the informal groups and networks of movements such as Charta 77, KOR or Solidarnosc. These structural patterns were not simply forced upon them by their necessarily conspiratorial nature. At the same time, their programmatic, radical scepticism of institutions and formal procedures of any kind, their "personnel policy" which relied entirely upon personal but not necessarily upon ideological loyalty manifested the network-based organization of social relations which typified life under real socialism in general, with its dual morality of private loyalty coupled with an evasive or disdainful approach to "public" concerns. After the transition, these behavioural patterns associated with what might be described as "unpolitical politics" or "anti-politics" soon came into conflict with the manner of their legitimation by the antitotalitarian values of a rational, sceptical, democratic, tolerant civil society. The need for the state in which the dissident groups participated during the initial phase to be subsequently restructured forced what had formerly been loose movements to become more institutionalized, decision-making to be formalized, and political standards to be set. Tolerance was thus transformed into the formal right of free expression, yet at the same time it ceased to be a principle of group discourse. ${ }^{30}$ The civic forums and round tables disintegrated into interest parties, and hence became institutions which are now engaged in a constant political war of attrition against one another before the public eye. This mechanism played no small part in the decline in the dissident groups' influence and the fact that their members have been displaced from the political scene.

Another factor acting as a major obstacle to the integrative effect of "civil society" as a concrete utopia is the unresolved relationship between political and economic order within the ideal. The communal model of a society organizing itself on a basis of solidarity is not readily compatible with the liberal concept of private property and the marketplace acting as society's self-ordering mechanisms. In this context, the demand for the restitution of

29 This would appear to confirm O'Donnell's observation that the means used to bring about a revolution are seldom suitable for managing the transformation necessary thereafter (O'Donnell/Schmitter 1986: 65).

30 An example of this development is provided by Fehr 1991; cf. also Tatur 1991. property which had been seized by the state was thematized not from an economic perspective but predominantly from an ethical one. Indeed, even the members of intellectual élites who were discussing this problem from political and economic perspectives believed that market socialism or "people's capitalism", including state or mixed ownership of enterprises with a considerable participating share to be held by their workforces, represented the most promising ways ahead, offering as they did the best assurance of full employment and social redistribution measures. ${ }^{31}$ The discrepancy between what actually happened with the advent of privatization in these economies and the above theoretical considerations on the economic system best suited for a post-socialist civil society is glaringly obvious. This discrepancy also therefore poses legitimation obstacles to the "antitotalitarian values" transported by the concrete utopia of civil society.

To sum up: while the move to political pluralism had always been a constituent element of the "civil society" concept - whatever the differing views on how to bring it about - the same could not be said at all for privatization in the economy. It was not until the transformation process gathered momentum that the concept of civil society began to undergo a change of meaning: the legitimating, antitotalitarian values have remained the same, but the social basis on which they are to be realized has now shifted away from a community in solidarity of the oppressed towards the liberal model of Smith's "invisible hand". However, against this background, a liberal market can ultimately only attain legitimacy as a means of attaining greater social justice, so the problems of ownership, privatization and associated policies are tending to be drawn into a vortex of moralization, while at the same time setting new criteria of social respect and disrespect. ${ }^{32}$ That too creates fault-lines in different groups' legitimatory view of themselves in these countries, which plays a significant part as far as acceptance of the transformation process is concerned.

31 This discussion was partly conducted in exile and partly in the countries themselves. See Brus 1990, Brus/Laski 1990, Sik 1990, pp. 97ff., Balcerovicz 1990. In Hungary, too, a good deal of emphasis was placed on the need to build a framework of social redistribution measures around a properly functioning market - on this, cf. Mänicke-Gyöngyösi 1991.

32 The "moral fundamentalism" of expectations borne by the concept of civil society is demonstrated by Tatur 1991, pp. $239 \mathrm{ff}$. 


\section{Elites}

The problem of the definitional power of élites and the acceptance, or otherwise, of that power which arises on the meaning level of the transformation process develops against a background in which alternative opposition élites are inevitably transformed into a functional elite supporting a new system. Viewed in ideal-typical terms, the counterélites in real socialist countries should be treated as value élites whose influence and legitimation are derived from the charisma of the ideas they advocate and/or the way they conduct their lives. These were alternative groupings characterized by the informality of their influence and of their social organization. In contrast to this, functional élites in their ideal-typical form are, at least formally, legitimated in terms of their qualifications and their performance, are formally vested with executive powers, and generally carry the main decisionmaking load in the social systems in which they take up the top political, economic, military and administrative positions. ${ }^{33}$ Hence, to the extent that functional élites, by instituting a division of labour in the organization of power, are able to hold it indefinitely, the transformation of a value elite into a functional élite will be accompanied by phenomena decribed by Max Weber himself ([1922] 1976: $681 \mathrm{ff}$.) when he demonstrated that a sustained stabilization of charismatic leadership would go hand-in-hand with transition to the everyday, i.e. with its transformation to establish a bureaucratic organization of power.

Which characteristics of this ideal-typical construct are discernible in the real world of the transformation of real socialism? Bearing in mind how the dissident elites viewed their own position as they advocated their anti-institutional concept of civil society, we gain some idea of the adjustment problems facing members of those élites by the transition to a new system. On the other side of the coin, the expectation at the level of everyday life which is also partly derived from the civil society concept is that societal institutions will again begin to function normally, and that also implies the further expectation that functional élites will act competently. From a structural point of view, this situation gives rise to two dilemmas which shape the relationship between elites and the general public in the post-socialist countries:

33 I have used the distinction between value and functional élites as made by Schluchter 1963, pp. $253 \mathrm{ff}$. on a basis provided by $O$. Stammer and Max Weber.
1. The legitimation of the oppositional value élites was chiefly founded on their quintessentially moral claim (Tatur 1991: $239 \mathrm{ff}$., Berking/Neckel 1991: 293, Havel 1980) "to live in truth" by matching their words and their deeds - a claim which at times takes on fundamentalist forms (Havel 1980: $29 \mathrm{ff}$.). The everyday plausibility of this moral claim flows from the collective schizophrenic experience of rejecting the regime while simultaneously accommodating to it. Yet it is accepted as one of the essential preconditions for the normalization of life and society associated with that moral claim that political pluralism and competent functional élites will be established. And that very process of realizing political pluralism which came with the transition divided up the members of what had previously been the alternative value élite into various interest groups, simultaneously propelling them into the now vacant positions and roles of the functional élite; the result was a new rivalry for definitional power among the transitional élites (Wendeeliten). The ensuing pragmatic necessity for political compromise naturally no longer permitted the ethical principles of action - i.e., purely value-rational action - to be upheld in full. The apparent lack of principles in political action is anathema to the transitional élite's legitimation claim (as a value élite) based on moral fundamentalism and hence invalidates that claim. The difficulty of translating the integrity of personal lifestyles into pragmatic, political action which becomes apparent at this stage ${ }^{34}$ has also been acting as a factor of selection in driving some of the dissidents back out of political life.

2. The second dilemma is a mirror image of the first. As the value élite begins to undergo functional change it not only loses its moral legitimation, but is also incapable of activating the new means of legitimation which applies to a functional elite quickly enough, i.e. legitimation on the basis of performance and competence. There are several reasons for this, as discussed below.

Due to their lack of professional experience and insufficient personnel resources, the élites of the transition period are forced to rely on the cooperation of the old functional elite and, informally at least, have to leave openings available for it to participate. Quite apart from the fact that this further undermines the new élite's moral legitimation, in the public's perception it also engenders doubts as to the competence not only of the transitional elite which has been forced to bring in outside help but On this problem, see Mänicke-Gyöngyösi 1990. 
also of their "auxiliary troops" from the old nomenklatura, who after all bear responsibility for the failure of real socialism.

Within the new élite formation which thus emerges, personal loyalty is an absolutely essential means of reducing complexity. So it was that new functional elites came to be recruited via the informal relationships existing in the networks to which the new holders of office belonged, all of whom formed their own retinues of assistants. Given that it was a practical impossibility that all the members of such networks would be suitably qualified for their new tasks, the situation arose in which unqualified people took up new offices simply on grounds of loyalty. That in itself might not have been so serious, had it not been for the fact that the recruitment procedure inevitably excluded people who did not belong to the right networks, who found themselves displaced by the asymmetry of the institutionalized position of those holding office. Though this system of patronage tends to stabilize people's positions within the individual groups constituting the new functional élite, it simultaneously widens the split between rival groupings within the overall structure. Both the patronage system and the displacement of other, qualified people from public office contravene the principle that a functional élite be legitimated in terms of its competence and performance. Moreoever, the end result is a copy of the recruitment and exclusion patterns which typified the old nomenklatura. Another phenomenon which fits in with this perceived pattern is the frequently "spontaneous" executive style, skirting around formal procedures, used by the new holders of office. Even if one admits that, from a structural viewpoint, those concerned have no other social techniques for organizing power available to them in the context of an executive system shaped by the conditions of real socialism, that does nothing to alleviate the delegitimating effect of such a management style. Beyond that lies a further danger which had already been identified by O'Donnell and Schmitter (1986: 66), namely that the techniques applied ad hoc during a period of transformation to reach pragmatic solutions to problems later tend, as they maintain, to become fully institutionalized mechanisms of the new order.

Similar effects are generated by the "helpyourself" tendencies already mentioned among the new functional elites, members of which exploit their inside knowledge and their positions to use the policy of privatization to establish their own businesses. ${ }^{35}$ The ease with which these people make use of the services and privileges associated with the positions and offices they hold, together with the fact that they inevitably adopt new forms of behaviour to match, ${ }^{36}$ completes this picture of an emerging style of recruitment and action in the new élites which integrates the old patterns of thinking and acting, thus providing an expansive target for popular resentment.

To sum up, the new élites contain only a small number of people whose integrity is assured by their past activities as dissidents in opposition and who can exercise an integrating, watchful role. In most cases, they are made up of former members of the functional élites operating under the old regime who, as such, are liable to be compromised at any time by "revelations" about their past. Since the overall atmosphere of the transformation process is one in which public perceptions are extraordinarily sensitive to moral considerations, the manner in which the new élites act is particularly strongly exposed to social respect or disdain. The criteria for these value judgments are derived to a considerable degree from drawing comparisons with the elites under the old regime who are classed as morally despicable. In the light of this pressure from the public perception, the need to be willing to compromise and be pragmatic in political actions undermines the moral legitimation formally enjoyed by the transitional élites as true value élites.

At the same time, the transitional élites are unable to activate any new legitimation as pluralist functional elites to a sufficient degree because the manner of their recruitment and the actions they take do not conform to the criteria of performance and competence oriented to the public at large. As a result, the implementation of economic privatization by the political elites is embedded in a framework which imposes a negative burden both on an élite itself and upon the prospective results of reform. Not only ought privatization to establish the economic conditions for reconstruction but, above all, it ought by installing proper market mechanisms to turn the economic sphere as a whole over to a civic process of self-regulation which is largely independent of the political sphere. Such relief of

35 A survey of Czechoslovakian members of parliament, for example, showed approximately $60 \%$ of them were active as private entrepreneurs. $\mathrm{Cf}$. $\mathrm{Li}$ dove noviny, 10.9 .92 , p. 1 .

36 On these mechanisms of self-representation, see Goffman 1983: 23ff. 
an entire system is not being achieved at present because, from the perspective of the comparability between the new élites and the old nomenklatura, the effects of the market observable to the public are interpreted as actions with a political intent to serve the interests of the new political class. The result is that decision-making power and responsibility for economic events continue to be attributed to that political class. A sensitive yet precise description of this state of affairs is provided by the recent coining of the terms "demokratura" and "nomenklatura capitalism". 37

How might it be possible to escape from the dilemmas I have illustrated? There are two typical courses of action which transitional élites might take as they transform theselves from value élites into functional élites, and both are indeed empirically in evidence in the post-socialist countries under consideration.

1. The transitional élites can endeavour to solve their legitimacy problems by resorting to moral legitimation schemes, i.e. by consolidating their reputation as value élites. They may do this by rejecting compromise politics and developing simple, binary schemes of judgment in accordance with the existing moral response pattern of respect-ordisdain. ${ }^{38}$ This allows them without difficulty to reactivate the habitual expectations developed under real socialism built around the dual, exclusive morality with its potential for establishing solidarity against "external foes". This type of solution is in evidence in the populist tendencies now apparent in Poland, Hungary and the Czech Republic, and also in the left-wing variant which has been able to assert itself in Slovakia.

2. The second possibility open to the transitional élite in order to resolve its legitimation problems is to devote itself fully to its role as a functional élite. In this position, there is a temptation to bridge the momentary gap posed by insufficiencies in competence and performance by taking a particularly authoritarian line ${ }^{39}$ This approach can, of course, be a component of the populist solution above, but in the Polish debate on the possibility of by-passing parliament to rule by decree it also has its technocratic variant. This variant, too, can readily pick up

${ }^{37}$ Both terms are now current in eastern European discourse: cf. Frankfurter Allgemeine 23.9.92, p. 5 and Lidové noviny 29.9 .92$, p. 1 .

38 On the simplification of evaluation schemes and intensification of conflict potential by "moralizing" action, see Luhmann 1980.

39 This is illustrated by Berking/Neckel 1991: 297. where the habitualized action orientations of real socialism have left off.

How should these developments be assessed with regard to the future course of the transformation process? We have worked on the assumption that an important part in shaping action orientations during the transformation process is played by the definitional power of élites, and hence also that the acceptance of these élites is an expression of willingness to bow to their definitional power. We added to this assumption Eisenstadt's thesis that élites are successful in a process of transformation if they fulfil the conditions of being autonomous in their definitional capacity, having good internal solidarity, and being regarded as legitimate by the general public. To what extent, then, are these conditions fulfilled by the reforming countries' transitional élites as they transform themselves?

The above analysis of the meaning dimension in the transformation of élites has clearly pointed up the associated legitimation problems. Internal solidarity within the various transitional élites now in the course of functional differentiation, which are nevertheless recruited via the informal networks of their own particular "chiefs" and characterized by rivalry to gain definitional power among particular groupings, can hardly be described as high. Any attempts to exercise definitional autonomy are therefore likely either to rely on the real-world asymmetry of power (i.e., to adopt an authoritarian line) or else to resort once again to a moralizing value legitimation by playing the populist card. Either of these approaches may result in the originally intended objectives of institutionalizing political pluralism being rendered unattainable.

\section{A Special Variant: The Former GDR/ New Federal States}

I have deliberately chosen to treat the local variant of the transformation process in the former GDR (new federal states) as a special case. That does not mean to say that the overall problems arising from privatization and political pluralization are essentially any different. What are quite different, however, are the frame conditions which also determine how these problems are dealt with. These differences in the frame conditions naturally include the obvious advantages accruing to the transformation process in the new federal states, namely large-scale financial assistance, administrative, political and technical expertise and immediate integration into the western transnational organiza- 
tions of which the Federal Republic of Germany has long been a member. Nevertheless, the preceding analysis suggests that here too, as in the other countries, there are a number of possible scenarios as to how the "modernizing" institutions will be implemented. In a nutshell, one might say that the particular frame conditions governing the transformation process in the new federal states are also giving rise to a particular set of obstacles.

Using the concept of civil society as a form of "probe" to bring these peculiarities into view, it is soon apparent that the first of the peculiarities in the situation of the former GDR is that this society did not develop its own idea of civil society as a concrete utopia; instead, the alternative to the existing regime consisted simply in joining what to all intents and purposes was a ready-made civil society. ${ }^{40}$ When set against this alternative as seen by the majority of the population, the peacemovement, ecological or reformed socialist concepts put forward by the country's intellectual opposition, which in any case was not widely articulated, appeared too abstract, too uncertain, and not forceful enough. The dissident movement which had been gathering since the mid-1980s did not have enough time to develop counter-élites with their own "designs" for future society (Wielgohs/Schulz 1993). The concrete utopia of accession to the Federal Republic not only promised that societal and political "normality", as already visible in concrete form, would presumably set in once the totalitarian regime had collapsed: more than that, it also promised unproblematic prosperity and material security. According to the evidence of electoral analyses and opinion polls, it would appear that the latter reason rather than any articulated desire for political normality, which was bound to come in any case, lent true appeal to the concrete utopia of reunification. ${ }^{41}$ However, it

40 Meyer (1993: 19) rightly points out that the protest actions which really triggered off the DDR's final crisis were not the street demonstrations calling for democracy but the preference for the other part of Germany expressed by those who joined the mass exodus.

41 On the primarily "material" electoral motivation in the former GDR after the transition, see Roth 1990 and also Bauer 1991, Gesincke 1991 and Offe 1993. A harsh judgment in this regard is made by Kurt Biedenkopf in: Smolar 1991/92: 19: "This prolonged phase of paternalistic organization of the state produced a population which truly was incapable, as indeed it continues to be to a considerable extent, of establishing autonomous societal structures, and which even today is largely unable to comprehend the principles of a civil society." is at the same time fair to assume that similar moral expectations were made of the "transformation by reunification", and of the actors carrying it out, to those coupled with the legitimation of the transitional élites in the other countries examined. That means that the anomic shock, which people in the former GDR have experienced just as their counterparts in the other post-socialist countries of central Europe have done as the economic and political systems have collapsed, now sits all the deeper.

Economic developments in the new federal states have shown what the future might hold for the other four countries if they were to carry out a radical privatization programme. Something in the order of $40 \%$ of the jobs previously available have now disappeared, and industrial production has fallen to approximately one third of its former level. Only the financial resources transferred from the west have been able to cushion the blow to a tolerable degree. That dependence brings us to a related special feature of the transformation process in the former GDR, namely that political forces in the country did not crystallize, and were not articulated, autonomously after the transition, and hence no transitional élite emerged which could be monitored according to the criteria of moral legitimation. The population of the old GDR was thus unable to control either political or economic developments on its own initiative, via an élite of its own. The problems and issues arising from economic and political developments - which in the experiential horizons of real socialism tend, as has been shown, to be regarded chiefly as the consequence of political actions taken by ruling élites cannot be dealt with using the mechanisms of moral discourse acquired by "home-grown" socialization, since they are understood and presented by western German managers and officials in the differentiated communication codes of their own "value-neutral" rationalities of the economic and administrative spheres. This asymmetry is manifested in semantically concentrated form in the use of the term "Abwicklung" when dealing with the former state institutions and enterprises [which has the dual English meaning of "dealing with" in the context of administrative business and "winding up" in commercial bankruptcy proceedings translator's note]. This poses a problem when it comes to establishing links between the action of western functional élites and the semantic inventory of those affected in the eastern part of the country. In other words, although the new federal states have avoided the legitimation dilemma associated 
with the transformation of value élites into functional élites in the other post-socialist countries, the new functional élite in operation there faces a legitimation problem of its own special kind.

If one applies Eisenstadt's thesis as a comparative matrix, the following picture emerges. The former intellectual elite of the country - in both its functional and its oppositional variants - has virtually no definitional power. On the other hand, the new political class in the new federal states is constrained in its definitional power because it is inevitably western-centred. As a result, it is barely able to adjust to local needs, and cannot act and communicate in the social codes handed down to it. To a considerable extent, it does not have a mastery of the semantics and patterns of real-socialist adjustment, nor is it able to derive any legitimacy from a "concrete utopia" which has developed organically within the new federal states. That political class is split according to its western or eastern origins, the split being deeper in terms of mentality than in those of political creed..$^{42}$ The composition of the new élite is itself a further feature peculiar to the new federal states. The western administration does have to rely, in a similar situation to the transitional élites of central Europe, on the cooperation of the old functional elites. However, in order to gain partners in the new federal states while nevertheless avoiding direct collaboration with the old nomenklatura it showed a preference for engaging the services of people who had worked for the old "block" parties of the official East German opposition, or for the churches and their administrative offices, though that is not to say that these people, too, could not be compromised. Yet despite this, the members of the old GDR administrative system have obviously still largely managed to hang on to their old positions..$^{43}$ Consequently, the new functional élite in the new federal states has what could virtually be termed a triangular configuration, linking together holders of office who come from the west, staff assigned to them who worked for the "fellow traveller" block parties or the churches, and finally the old bureaucracy. At

${ }^{42}$ Cf. Allensbacher Berichte 1992: 40 , stating that $43 \%$ of "western experts" surveyed see the greatest problem in possible cooperation with eastern Germans consisting in differences of mentality. On such differences, see also Koch 1991 and 1992.

${ }^{43}$ Only $20 \%$ of the civil service jobs in the former GDR have been lost, whereas $50 \%$ of industrial and $70 \%$ of agricultural jobs have disappeared. The figures, referring to 1992, are taken from Südkurier 17.10.92, p. 6 . the local level, the mixture has a further ingredient in the representatives of the former citizens' movement. ${ }^{44}$ From the perspective of everyday observers, the western component of the élite's triangular structure appears, given its definitional power and inside information, to have taken over the position previously occupied by the Party (Berking/Neckel 1992: 166ff.). That would also correspond with the tendencies observed in the other countries.

It is already clear at this point that the transformation process in the new federal states needs to overcome a number of special obstacles, even though it has the benefit of a substantial lead over the other countries in terms of technocratic, administrative and political knowledge, and of course is being implemented with abundant financial support. On the meaning level, the process would appear to be characterized by a collective experience described by Alfred Schütz in his study on strangers (Schütz 1971: 59ff.): because the attempt is being made to integrate the two parts of the country on the basis of mutual prior knowledge which has not been mediated by concrete interaction, the differences between them are being brought out more clearly than ever. ${ }^{45}$ Discovering this "otherness", which was also felt to be one of inferiority, the former citizens of the GDR thus also discovered a GDR identity of their own which they had not felt before reunification, and which had not previously been filled out with any socially (rather than politically) accepted substance institutionalized on a symbolic level. This is an empty space for which, though it is already preshaped by a number of options from the outside in, the inner structure is only beginning to develop.

Once again, one of the most important indicators of how that empty space is indeed being shaped is the level of acceptance for privatization and its consequences for the shaping of political pluralism. It is quite reasonable to assume that such acceptance is not uniform but, as in the other countries, differs quite substantially from one section of

44 Cf. Berking/Neckel 1991 \& 1992. The local transitional élite described in their case study would appear to be by no means unusual. According to Wielgohs/Schulz (1993: 239), the citizens' movement is active in all urban municipalities, $74 \%$ of the district towns and $47 \%$ of the smaller towns.

45 It is no coincidence that surveys of geographical differences in public attitudes in the new federal states show that scepticism of the political order of former West Germany is at its highest among inhabitants of the region which used to lie on the western border of the old GDR - cf. Liebig 1993. 
the public to another. Dwindling confidence in the market economy and the efforts now being made by local interest groups and authorities to preserve the old industrial infrastructure for the sake of similarly preserving jobs also give a clear indication. ${ }^{46}$ Huinink and Mayer (1993: $166 \mathrm{ff}$.) point out the likelihood of a "chain of lost generations" in the new federal states, deprived by the political transition and privatization process of the opportunity to become newly integrated, and partly also of the chance of upward social mobility. Given that the public's means of articulating itself using the codes and channels now provided by the west, though theoretically many and varied, are in fact now more constrained if anything because of the insecurity that variety itself has created, and given also that interests are not being articulated politically by any autonomously crystallized élite, we have to try to identify the latent scenarios for the formation of a new identity. Such scenarios are only conceivable as a continuation and adaptation of the action orientations which predominated under real socialism. Analyses of eastern German lifestyles and consciousness have particularly highlighted the petty bourgeois character which was conserved and generalized in the GDR (Woderich 1991 \& 1992). If this is so, we have a situation in which the exclusion and inclusion effects of moral respect or disdain typified by the dual (in-group/out-group) morality existing in the real socialist setting was amplified still more by the petty bourgeois tendency to adopt a highly sensitive moral posture towards social extremes and deviant behaviour. ${ }^{47}$ These orientation patterns shaping the societal structure under real socialism are reported to have been particularly pronounced in the GDR because of its greater isolation both from the outside world and within its own society (Woderich 1992). Against this background, it is not only possible to conceive of a "normal" course of developments as posited by the theory of "institutional modernization" but

46 For a representative account, see Berking/Neckel 1992 , pp. 160f. According to opinion polls carried out by the Allensbach institute, acceptance of the market economy in the former GDR fell from $77 \%$ in 1990 to $35 \%$ in 1993. Cf. Frankfurter Allgemeine 9.9.92, p. 5 and 16.12 .93 , p. 5 .

47 This structure of the petty bourgeois mentality has already been identified by Geiger (1987: 85ff. \& $108 \mathrm{ff}$.) and Lipsett (1992: $136 \mathrm{ff}$.) in their enquiries into the affinity between the petty bourgeoisie and Nazism. On post-war manifestations of this structure, cf., e.g., Jung 1982 and Eder 1989. also of certain other scenarios for filling the "empty space" of collective identity:

a) The expected protest attitudes in the east due to the perceived deprivation of social status are not articulated and communicated by political élites and institutions which can be regarded as autonomous. The autonomy of trade unions which does still go some way in this direction is considerably restrained by economic pressure to maintain the east-west wage differential. To that must be added the fact that "democracy" has a relatively low priority as an object of identification compared to economic stability. ${ }^{48}$ An objective chance therefore exists that, here too, means of articulation may be sought which lie outside the established spectrum of politics. That is to say that the field is open, in structural terms, for populist alternatives on the Left or Right, as has been seen in the other countries under review. For one thing, the successor organization to the old ruling party is now establishing a position as an advocate of the people's interests in the former GDR which is independent of the west; $31 \%$ of those people, incidentally, would welcome a return to socialism under certain circumstances. ${ }^{49}$ On the other hand, another element of the semantic horizon of new-found freedom is the rejection of anti-fascism which belonged to the totalitarian ideological compulsions of the GDR regime. Moreover, the combination of a downgraded social status and growing uncertainty on the one hand and the old, exclusive dual morality on the other reinforces the tendency for new identity aids to be grasped which are derived from the chance event of belonging to a particular ethnic group or particular geographic region. Thus the willingness to engage in solidarity along such lines provides an imperfect basis upon which nationalism is not yet specifically (say, politically) articulated, but instead is manifested for the time being in blunt violence against the foreigners people feel have been forced upon them - or, to be more precise, against the strangers and strangeness forced upon them. An empty space delineated by such prepolitical nationalism could indeed also be filled by populism of a right-wing stripe.

b) The feeling of inferiority in the east, and of having been labelled second-class citizens, coupled with an awareness of being totally dependent on

48 Cf. Westle 1992: $28 \mathrm{ff}$. The lower priority attached to democratic values relative to material prosperity is also noted by Bauer 1991 and Gesincke 1991.

49 Allensbacher Monatsbericht, Frankfurter Allgemeine 16.12 .93 , p. 5 . 
the west both economically and politically, might activate a.willingness to establish exclusive solidarity which, despite yet also because of that dependence, generates the demand for symbolically institutionalized upgrading (not merely material or formally legal improvements), as a manifestation of parity in the reunified Germany. If it proves impossible to achieve this symbolic upgrading with the aid of established political forces, there is a distinct possibility of alternative movements emerging to further that aim. Given the constellation of structural problems, this scenario might well imply the "Slovakification" of the new federal states in the long term.

The above two scenarios pose a threat of destabilization for Germany as a whole. Thus what at first sight are the advantages enjoyed by the transformation process in the former GDR - the extensive financial support, the opportunity to accede to a stable, well-ordered existing political structure, the availability of experienced administrative experts - have, during the execution of the process, actually set off a momentum of their own which is liable to undermine the stabilizing effects flowing from those advantages. The entire Federal Republic of Germany is thus implicated in the imponderables of central European transition.

\section{Conclusions}

What conclusions can be drawn from the observations made in this paper when reviewing the assumption of "ongoing modernization"? As has been shown, the ideal-typical link posited between political pluralism and the market economy is not, whatever the rhetoric may say, an automatic link as far as the central European transformation process is concerned. Enthusiasm for political pluralism is not necessarily accompanied by an acceptance of privatization; nor, conversely, does a positive attitude to the market economy and its related consumption patterns necessarily imply a preference for parliamentary democracy. Evidently, the crucial issue here is not "small-scale privatization" (providing private-sector access to wholesaling and retailing, services and small or medium-sized productive enterprises): the privatization of largescale industry is where the social dynamite lies, and this is acting as a catalyst for the differing courses taken by the transformation process in the countries under review. As the case of the GDR illustrates, even the strongest guarantors are not able to deal with the social upheavals triggered off by radical privatization without undergoing risks. It is also clear that the hesitancy to take radical steps in this direction currently evident in Poland, the Czech Republic, Slovakia and Hungary is not without good reason, and cannot be attributed solely to the intrigues hatched by those belonging to the old structures. The danger is all too real that the bursts of anomie now triggered off could intensify the polarization and radicalization of society.

If, in the light of the background situation described here, we assess the chances of the modernization mechanisms postulated at the outset truly functioning in accordance with the theory, it is clear that it would still be premature to say quite unequivocally how those mechanisms will operate. On the normative level, social inclusion is counteracted by strong social or also ethnic exclusive tendencies which can be traced back to the dual morality operating under real socialism. The same tendency also has a counteractive effect against value generalization. Meanwhile, the differentiation of economic, political and social logics of action within the structure of everyday expectations has so far been thwarted by the perception inherited from real socialism that all economic, political and social events are consequences of the actions taken by political élites, whose ultimate aims are self-preservation and self-enrichment. Likewise, the structural differentiation of social positions and new initial opportunities has not even come close to generating adaptive upgrading across the board. Rather, the trends now suggesting themselves point towards real exclusion - not solely normative exclusion - of the social strata whose output is low, as a result of the new mechanisms for upward social mobility created by privatization.

Thus it is quite likely that the development curve of the transformation process could have a different shape from that suggested by a globally applied theory of institutional modernization. Moreover, even if developments are optimum under the terms of the theory, we still should not expect the interaction between meaning-worlds derived from the real socialist period and western-style institutions to produce post-socialist societies which are pure copies of their western models. Of course, that does not mean to say that all research on modernization should be dismissed. Sociological theory, including modernization theory, has enough approaches on offer which can indeed provide adequate access to the transformation process now taking place in the post-socialist countries. But as the differentiated view developed in this paper shows us, the road ahead does not lead dead 
straight towards "civil society": it also has many distracting forks and turn-offs, some of which may simply be detours, but others of which can surely prove to be wrong-turnings.

\section{References}

Allensbacher Berichte, No. 7, 1991: Institut für Demoskopie Allensbach

Allensbacher Berichte, No. 3, 1992: Institut für Demoskopie Allensbach

Andorka, R., 1992: Ursachen, Probleme und Lösungsstrategien in der Revolution in Ungarn. pp. 45-54 in Schäfers, B. (ed.), Lebensverhältnisse und soziale Konflikte im neuen Europa. Verhandlungen des 26. Deutschen Soziologentages, Frankfurt/M.: Campus

Andorka, R., 1992a: Die wirtschaftlichen, gesellschaftlichen und politischen Transformationsprozesse in Ungarn im Lichte soziologischer Forschungsergebnisse. in Thomas M. (ed.) Abbruch und Aufbruch, Berlin: Akademie Verlag

Ash, T. G., 1990: Ein Jahrhundert wird abgewählt. München/Wien: Hanser

Balcerowicz, L., 1990: Definitionsprobleme des Sozialismus in der heutigen Welt. pp. 69-81 in Sik (ed.)

Bauer, P., 1991: Politische Orientierungen im Übergang. Eine Analyse politischer Einstellungen der Bürger in West- und Ostdeutschland. Kölner Zeitschrift für Soziologie und Sozialpsychologie 43: 433453

Beckherrn, E., 1991: Tal der Wende. Wohin steuert Osteuropa? München: Knaur

Berger, P.L./Luckmann, Th., 1970: Die gesellschaftliche Konstruktion der Wirklichkeit. Frankfurt/M.: Fischer

Berger, P.A., 1992: "Was früher starr war, ist nun in Bewegung" - oder: Von der eindeutigen zur unbestimmten Gesellschaft, pp. 128-151 in Thomas (ed.)

Berking, H./Neckel, S., 1991: Außenseiter als Politiker. Rekrutierung und Identitäten neuer lokaler Eliten in einer ostdeutschen Gemeinde. Soziale Welt 42(3): 283-299

Berking, H./Neckel, S., 1992: Die gestörte Gemeinschaft. Machtprozesse und Konfliktpotentiale in einer ostdeutschen Gemeinde. pp. 151-171 in Stefan Hradil (ed.), Zwischen Bewußtsein und Sein, Opladen: Westdeutscher Verlag

Bertels, L. (ed.), 1993: Gesellschaft, Stadt und Lebensläufe im Umbruch. FernUniversität Hagen

Boguszak, M./Mateju, P.,/Gabal, I., 1990: Ke koncepcim vyvoje socialni struktury v CSSR. (Über Konzeptionen der Entwicklung von Sozialstruktur in der CSSR), Sociologicky casopis 26: 168-186

Brockl, L., 1992: Between November 1989 and democracy - antinomies of our politics. Czechoslovak sociological Review, 28(2): pp. 150-164,

Brus, W./Feher,F./Michnik, A., 1981: Polen: Symptome und Ursachen der politischen Krise. Hamburg: VSAVerlag
Brus, W., 1990: Das Konzept auf dem Prüfstand. pp. 53-68 in Sik (ed.)

Brus, W./Laski, K., 1990: Von Marx zum Markt. Der Sozialismus auf der Suche nach einem neuen Wirtschaftssystem. Marburg: Metropolis

Bruszt, L., 1990: 1989 - The Negotiated Revolution in Hungary. Social Research 57: 365-387

Buchner-Jeziorska, A., 1992: Psychosoziale Barrieren im TransformationsprozeB polnischer Ökonomie. pp. 273-288 in Dittrich, E. (ed.), Der Wandel industrieller Beziehungen in Osteuropa. Frankfurt/M.: Campus

Butorova, Z. u.a., 1992: Aktuálne problèmy CeskoSlovenska - Január 1992 (Aktuelle Probleme der Tschecho-Slowakei) Januar 1992 Bratislava

Cermakova, M., 1991: Raport o postaveni zeny $\mathrm{v}$ roce dva (Report on the Position of Women in Year Two), Prague: Manucript

Dahrendorf, R., 1990: Betrachtungen über die Revolution in Europa. Stuttgart: Deutsche Verlagsanstalt

Deppe, R./Dubiel H./Rödel U., 1991: Demokratischer Umbruch in Osteuropa. Frankfurt/M.: Suhrkamp

Dittrich, E., (ed.), 1992: Der Wandel industrieller Beziehungen in Osteuropa. Frankfurt/M.: Campus

Ebert, E., 1992: Probleme der Einkommensentwicklung, - differenzierung und -verwendung im TransformationsprozeB. Berliner Journal für Soziologie 3: 319-342

Eder, K., 1989: Jenseits der nivellierten Mittelstandsgesellschaft. Das Kleinbürgertum als Schlüssel einer Klassenanalyse in fortgeschrittenen Industriegesellschaften. in Eder (ed.), Klassenlage, Lebensstil und kulturelle Praxis. Frankfurt/M.: Suhrkamp

Eisenstadt, S.N., 1979: Tradition, Wandel, Modernität. Frankfurt/M.: Suhrkamp

Fehr, H., 1991: Solidarnosc und die Bürgerkomitees im neuen politischen Kräftefeld Polens. pp. 256-280 in Deppe, R. (ed.), Demokratischer Umbruch in Osteuropa, Frankfurt/M.: Suhrkamp

Frentzel, Zagorska, J., 1990: Civil Society in Poland and Hungary. in Soviet Studies 42: 759-777

Frydman, R./Rapaczynski, A., 1991/92: Wieviel Staat braucht der Markt? in Transit, 3: 193-205

Galasi, P./Sziraczki, G. (eds). 1985: Labour Market and Second Economy in Hungary. Frankfurt/M.

Galasi, P., 1985: Extra Income and Labour Market Position. pp. 293-316 in derselbe, Sziraczki, G. (eds)

Geiger, Th., [1932] 1987: Die soziale Schichtung des deutschen Volkes. Stuttgart: Enke

Geißler, R., 1991: Transformationsprozesse in der Sozialstruktur der neuen Bundesländer. Public 2: 47-78

GeiBler, R., 1992: Die Sozialstruktur Deutschlands. Opladen: Westdeutsche Verlag

Gellner, E., 1991: Nationalismus und Moderne. Berlin: Rothbuch-Verlag

Gellner, E., 1992: Nationalismus in Osteuropa. Wien: Passagen-Verlag

Gesincke, Th., 1991: Vom Pessimismus zum Optimismus und vom "konservativen" Protest zur Selbständigkeit. Public 4: 98-122 
Goffman, E., 1983: Wir alle spielen Theater. Selbstdarstellung im Alltag. München: Piper

Habermas, J., 1990: Vergangenheit als Zukunft. Zürich: Pendo-Verlag

Hankis, E., 1988: The "second society": Is there an Alternative social Model emerging in Contemporary Hungary? Social Research 55: 13-42

Hankis, E., 1990: Zwischen zwei Welten. Wertewandel in Ungarn. Transit 4: 167-184

Havel, V. 1991: Letní premitaní. (Summer Meditation) Praha: Odeon

Havel, V., [1978] 1990: Moc bezmocnych (Power of the Powerless). Brno: Host

Havel, V., 1980: Versuch, in der Wahrheit zu leben. Von der Macht der Ohnmächtigen. Reinbeck: Rowolth

Hefty, G.P., 1992: Csurkas Kampfansage an Antall. Frankfurter Allgemeine Zeitung 9.9.1992: 12

Heidenreich, M., 1994: Die mitteleuropäische Großindustrie im Transformationsprozeß. Zeitschrift für Soziologie 23: 1-19

Horkheimer, M., 1988: Traditionelle und kritische Theorie. in Horkheimer, Gesammelte Schriften vol. 4: $193 \mathrm{ff}$, Frankfurt/M.: Fischer

Horn, G., 1992: Im Tal der Tränen. Spiegel 28: 152-154

Huinink, J./Mayer, K.U., 1993: Lebensläufe im Wandel der DDR-Gesellschaft. pp. 151-171 in Joas, H./ Kohli, M. (ed.), Der Zusammenbruch der DDR. Frankfurt/M.:

Jowitt, K., 1983: Soviet Neotraditionalism: The Political Corruption of a Leninist Regime. Soviet Studies 35: 275-297

Jung, D., 1982: Vom Kleinbürgertum zur deutschen Mittelschicht. Analyse einer Sozialmentalität. Saarbrücken: "Die Mitte"

Kabele, I., 1992: Ceskoslovensko na ceste od kapitalismu ke kapitalismu (Czechoslovakia on the Road from Capitalism to Capitalism). Sociologicky casopis 28: 4-21

Koch, Th., 1992: "Hier ändert sich nie was!" Kontinuitäten, Krisen und Brüche ostdeutscher Identitäten im Spannungsfeld zwischen "schöpferischer Zerstörung" und nationaler Re-Integration. pp. 319-334, in Thomas (ed.)

Koch, T./Thomas., M./Woderich, R., 1993: Akteurgenese und Handlungslogiken - Das Beispiel der "neuen Selbständigen" in Ostdeutschland. Berliner Journal für Soziologie 3: 275-292

Koch, Th., 1990: Die "deutscheren" Deutschen historisch-kulturelles Selbstverständnis, Mentalitäten, Identitäten im intrakulturellen Vergleich. Manuscript, Berliner Institut für sozialwissenschaftliche Studien

Koch, Th., 1991 Statusunsicherheit und Identitätssuche im Spannungsfeld zwischen "schöpferischer Zerstörung" und nationaler Re-Integration. Public 2: 79-98

Köcher, R. 1992: Die Ostdeutschen frösteln in der Freiheit. (Allensbacher Berichte), Frankfurter Allgemeine Zeitung 9.9.1992, pp. 5

Kolarska-Bobinska, L./Rychard, A., 1990: Economy and Polity: Dynamics of Change. Social Research 57: 303-320
Kolarska-Bobinska, L., 1988: Social Interests, Egalitarian Attitudes and the Change of Economic Order. Social Research 55: 111-138

Kolosi, T./Rona-Tas, A., 1992: Posledni bude prvni? (Will the Last be the First?), Sociologicky casopis 28: 579-598

Konrád, G., 1984: Antipolitik, Mitteleuropäische Meditationen. Frankfurt/M.: Suhrkamp

Konrád, G., 1992: Interview in Lidovè noviny, 10.10.1992 Sonntagsbeilage, pp. 1 und 2

Kornai, J. 1980: Economy of Shortage. 2 Bde. Amsterdam

Kuron, J. 1993: Man mu träumen können. Soziale Gerechtigkeit als soziale Bewegung. Transit 3, Heft 6: 6-24

Liebig, St., 1993: Gerechtigkeitseinschätzung und Legitimation im Vereinigungsprozeß: Die Rolle des grenznahen Wohnorts in der ehemaligen DDR. in Berliner Journal für Soziologie, 3: 57-74

Lipset, S.M., 1962: Soziologie der Demokratie. Darmstadt: Luchterhand

Luckmann, Th., 1986: Grundformen der gesellschaftlichen Vermittlung des Wissens: kommunikative Gattungen. Kultur und Gesellschaft, Sonderheft der Kölner Zeitschrift für Soziologie und Sozialpsychologie 27: 192-211

Ludwig, M., 1992: Agenten an der Macht, Volk in Not. Frankfurter Allgemeine Zeitung 16.8.1992, p. 3

Luhmann, N., 1980: Paradigm lost: Über die ethische Reflexion der Moral. Frankfurt/M.: Suhrkamp

Lukacs, J., 1992: Neue Strukturen zwischen Markt und Staat in Ungarn. pp. 289-299, in Dittrich (ed.) Der Wandel industrieller Beziehungen in Osteuropa. Frankfurt/M. Campus

Manchin, R., 1988: Individual Economic Strategies and Social Consciousness. Social Research 55: 77-95

Mänicke-Gyönagyösi, K./Rytlewski, R., (eds), 1990: Lebensstile und Kulturmuster in sozialistischen Gesellschaften. Köln: Wissenschaft und Politik

Mänicke-Gyöngyösi, K., 1991: Bürgerbewegungen, Parteien und "zivile" Gesellschaft in Ungarn. pp. 221-233, in Deppe, R. (ed.), Demokratischer Umbruch in Osteuropa, Frankfurt/M.: Suhrkamp

Mänicke-Gyöngyösi, K., 1990: Sind Lebensstile politisierbar? Zu Chancen einer "zivilen Gesellschaft" in Ost- und Ostmittel-Europa. Politische Vierteljahresschrift, Sonderheft 20: 335-350

Marody, M., 1988: Antinomies of Collective Subconsciousness. Social Research 5: 97-110

Marody, M. 1990: Perception of Politics in Polish Society. Social Research 57: 257-274

Mateju, P., 1992: Od nespravedlivè rovnosti k spravedlive nerovnosti? Nazory na nerovnost a socialḿ spravedlnost (From UnjustEquality to Just Inequality? Opinions on Inequality and Social Justice) in Data a fakta 2, Research reports of the sociological institute CSAV

Mateju, P./Tucek, M., 1992: Declared Occupational Mobility and the Change in the Role of Achievment Principles in four Nations of East-Central Europe. Czechoslovak Sociological Review, Special Issue, August: $123-129$ 
Merton, R., 1968: Social Theory and Social Structure. New York/London: Macmillan Press

Meyer, G., 1993: Die politischen Kulturen Ostmitteleuropas im Umbruch. pp. 3-13, Aus Politik und Zeitgeschichte, Beilage zur Wochenzeitung Das Parlament 5.3.1993

Michalski, K. (ed.), 1991: Europa und die Civil Society. Stuttgart: Klett-Cotta

Michnik, A., 1985: Letters from Prison and other Essays. Berkeley, Ca.

Michnik, A., 1981: Was wir wollen und was wir können. in Brus

Mozny, I., 1991: Proc tak snadno...? (Why So Easy ...?), Praha: Sociologickè nakladeltství

Müller-Hartmann, I., 1993: Soziale Lage, soziale Risiken und ihre Bewältigung in den neuen Bundesländern. Berliner Journal für Soziologie 3: 303-318

Musil, I., 1992: Czechoslovakia in the Middle of Transition. Czechoslovak Sociological Review. Special Issue August: 5-22

Novak, St., 1988: Polish Society in the Second Half of the 1980s: An attempt to Diagnose of the State of Public Consciousness. in IREX occasional papers, January

O'Donnell, G./Schmitter, Ph.C., 1986: Transitions from Authoritarian Rule. Tentative Conclusions about Uncertain Democracies. Baltimore/London: Johns Hopkins University Press

Offe, C., 1991: Das Dilemma der Gleichzeitigkeit. Demokratisierung und Marktwirtschaft in Osteuropa. Merkur 505: 279-292

Offe, C., 1993: Wohlstand, Nation, Republik. Aspekte des deutschen Sonderweges von Sozialismus zum Kapitalismus. pp. 282-301 in Joas, H./Kohli, M. (eds), Der Zusammenbruch der DDR. Frankfurt/ M.: Suhrkamp

Offe C., 1993a: Die Integration nachkommunistischer Gesellschaften: Die ehemalige DDR im Vergleich zu ihren osteuropäischen Nachbarn. pp. 806-817 in Schäfers, B. (ed.), Lebensverhältnisse und soziale Konflikte im neuen Europa. Verhandlungen des 26. Deutschen Soziologentages, Frankfurt/M.: Campus

Parsons, T., 1972: Das System moderner Gesellschaften. München: Juventa

Plessner, H., 1982: Die verspätete Nation. Über die politische Verführbarkeit des bürgerlichen Geistes. in derselbe, Gesammelte Schriften vol. 6, Frankfurt/ M.: Suhrkamp

Robert, P., 1990: Mobilitätsprozesse in Ungarn unter besonderer Berücksichtigung der Kultursphäre. pp. 142-160 in Mänicke-Gyöngyösi/Rytlewski (eds),

Schluchter, W., 1963: Der Elitebegriff als soziologische Kategorie. KZfSS, pp. 233-256

Schütz, A., 1971: Der Fremde, in Schütz, Gesammelte Aufsätze vol. II, Den Haag: Nijhoff

Shils, E., 1991: Was ist eine Civil Society? in Michalski (ed.) Europa und die Civil Society. Stuttgart: KlettCotta

Sik, O. (ed.), 1990: Die sozialgerechte Marktwirtschaft. Ein Weg für Osteuropa. Freiburg i.B.: Herder
Siklová, J., 1991: Nationalismus in Ost- und Mitteleuropa. Frankfurter Allgemeine Zeitung 4.9.1991, pp. 10

Siklová, J., 1990: The "Gray Zone" and the Future of Dissent in Czekoslovakia. Social Research 57: 347363

Slejska, D., 1993: Socialne ekonomicka situace a nazory na ni; Cesi a Slovaci. (Attitudes to the SocioEconomic Situation; Czechs and Slovaks in Slejska, Enquiries on "Work" as a Value), Centre for Empirical Research at the Sociological Institute of the Academy of Sciences, Prague.

Smolar, A., 1991: Drei Politiker und Denker des Übergangs. Transit 3: 19-33

Srubar, 1., 1991: War der reale Sozialismus modern? KZfSS 43: 415-433

Staniszkis, J., 1991: Dilemmata der Demokratie in Osteuropa. pp. 326-347. in Deppe, R./Dubiel, H./ Rödel, U. (eds), Demokratischer Umbruch in Osteuropa. Frankfurt/M.: Suhrkamp

Stark, D., 1992: Privatisierungsstragegien in der CSFR, Ostdeutschland, Polen und Ungarn. ein Vergleich. Transit 3: 177-192

Stieler, B., 1992: Die ökonomische Situation der Frauen in den neuen Bundesländern. Berliner Journal für Soziologie 2: 59-66

Stojanov, Chr., 1992: Die postsozialistische Transformation - eine eigenartige (Re-)Modernisierung. pp. 1942 in Dittrich (ed.) Der Wandel industrieller Beziehungen in Osteuropa. Frankfurt/M. Campus

Szacki, J, , 1990: A Revival of Liberalism in Poland? Social Research 57: 463-491

Sztompka, P, 1993: Civilizational Incompetence: The Trap of Post-Communist societies. Zeitschrift für Soziologie 22: 88-95

Tatur, M., 1991: Zur Dialektik der "civil society" in Polen. pp. 234-255, in Deppe, R. (ed.), Demokratischer Umbruch in Osteuropa, Frankfurt/M.: Suhrkamp

Taylor, Ch., 1991: Die Beschwörung der Civil Society. in Michalski (ed.) Europa und die Civil Society. Stuttgart: Klett-Cotta

Thomas, M. (ed.), 1992: Abbruch und Aufbruch. Berlin: Akademie Verlag

Titkow, A., 1992: Frauen in Polen. Berliner Journal für Soziologie 2: 49-57

Vecernik, J., 1991: Nezamestnanost: Obavy znacne diferencovane (Differing Fears on Unemployment) in Data a fakta 1, Research Reports of the Sociological institute CSAV

Voslensky, M., 1980: Nomenklatura. Die herrschende Klasse der Sowjetunion. Wien: Molden

Weber, M., 1976: Wirtschaft und Gesellschaft. Tübingen: Mohr

Westle, B., 1992: Unterstïtzung des politischen Systems. in Möller, P.,Ph./Bandilla, W. (ed.) Blickpunkt Gesellschaft. Einstellungen und Verhalten der Bundesbürger in Ost und West. Opladen: Westdeutscher Verlag

Wielgohs, I./Schulz, M., 1993: Von der "friedlichen Revolution" in die politische Normalität. Entwicklungsetappen der ostdeutschen Bürgerbewegung. 
pp. 222-245 in Joas. H./Kohli, M. (ed.), Der Zusammenbruch der DDR. Frankfurt: Suhrkamp

Woderich, R., 1991: Auf der Suche nach der "verborgenen" Mentalität der Ost-Deutschen. Public 3: 121132

Woderich, R., 1992: Mentalitäten im Land der kleinen Leute. in Thomas, pp. 76-90

Zapf, W., 1991: Der Untergang der DDR und die soziologische Theorie der Modernisierung. pp. 38-51, in Giesen, B./Leggewie, C. (ed.), Experiment Vereinigung. Berlin:
Zapf, W., 1991a: Die DDR 1989/1990 - Zusammenbruch einer Sozialstruktur? in Berliner Journal für Soziologie 1(2): 147-157

Zapf, W., 1993: Die DDR 1989/1990 - Zusammenbruch einer Sozialstruktur? pp. 29-48 in Joas H./Kohli, M. (eds), Der Zusammenbruch der DDR. Frankfurt/ M.: Suhrkamp

Ziemer, K., 1989: Auf dem Weg zum Systemwandel in Polen. I und II. in Osteuropa 39: 791-805, 957-980

Ziolkowski, M., 1988: Individuals and the Social System: Values, Perceptions and Behavioral Strategies. Social Research 55: 139-177 